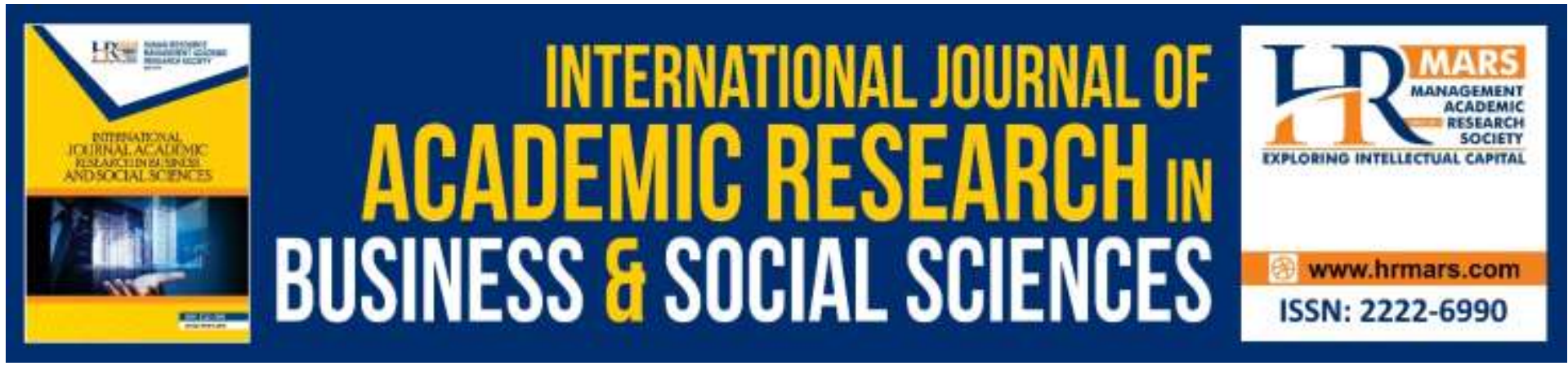

\title{
Ageing Population and Economic Growth: An Empirical Investigation
}

Nur Hayati Abd Rahman, Shafinar Ismail, Abdul Rahim Ridzuan

To Link this Article: http://dx.doi.org/10.6007/IJARBSS/v10-i5/7234

DOI:10.6007/IJARBSS/v10-i5/7234

Received: 17 March 2020, Revised: 22 April 2020, Accepted: 15 May 2020

Published Online: 30 May 2020

In-Text Citation: (Rahman et al., 2020)

To Cite this Article: Rahman, N. H. A., Ismail, S., \& Ridzuan, A. R. (2020). Ageing Population and Economic Growth: An Empirical Investigation. International Journal of Academic Research in Business and Social Sciences, 10(5), 609-625.

Copyright: (c) 2020 The Author(s)

Published by Human Resource Management Academic Research Society (www.hrmars.com)

This article is published under the Creative Commons Attribution (CC BY 4.0) license. Anyone may reproduce, distribute, translate and create derivative works of this article (for both commercial and non-commercial purposes), subject to full attribution to the original publication and authors. The full terms of this license may be seen

at: http://creativecommons.org/licences/by/4.0/legalcode

Vol. 10, No. 5, 2020, Pg. $609-625$

Full Terms \& Conditions of access and use can be found at http://hrmars.com/index.php/pages/detail/publication-ethics 


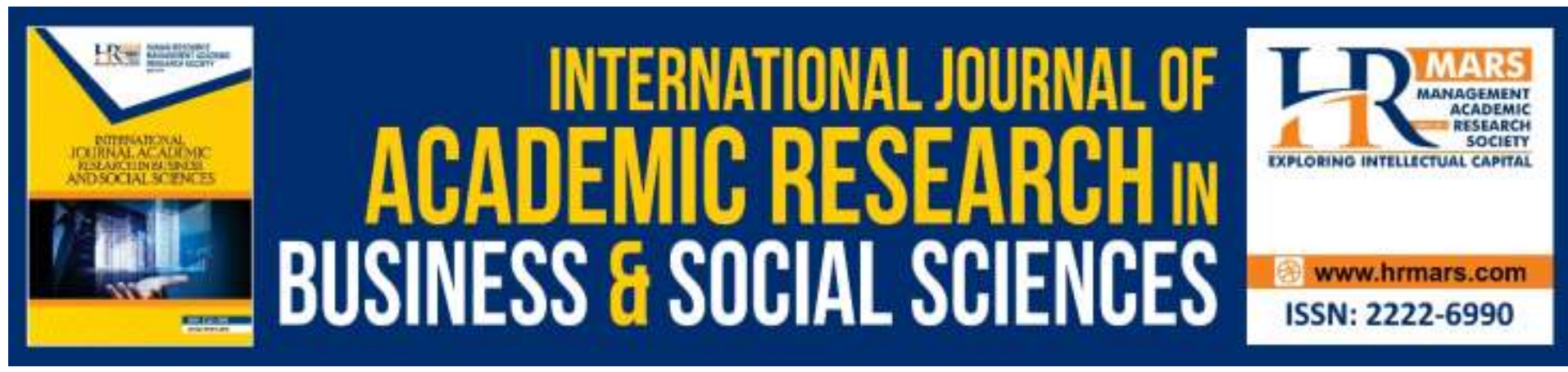

\title{
Ageing Population and Economic Growth: An Empirical Investigation
}

\section{Nur Hayati Abd Rahman, Shafinar Ismail, Abdul Rahim Ridzuan}

Faculty of Business and Management, Universiti Teknologi MARA Melaka, Malaysia Email: nurhayati.uitmt@gmail.com

\begin{abstract}
Due to a rise in the ageing population, the upper-middle-income economies might not be able to embrace the fourth industrial revolution, thus limiting their ability to achieve highincome economies. This paper aims to investigate how the increase in the ageing population affects the economic growth of the 32 countries in the upper-middle-income economies from 1990 to 2018. By employing system GMM, the finding shows that the ageing population does adversely affect the economic growth of the upper-middle-income economies as outlined by the theory of secular stagnation. This finding requires special attention for the governments to redesign their fiscal policy by focusing on higher budget allocation on education and critical sectors. It is with a hope that the long-term growth will increase eventually even when the countries are facing a rise in the ageing population. Future researchers may extend this study by examining how ageing population affect the public debt of a country.

Keywords: Ageing Population, Economic Growth, Upper-Middle-Income Economies, System GMM, Theory of Secular Stagnation.
\end{abstract}

\section{Introduction}

The world is currently facing a problem of a high ageing population (Abeywardhana, 2019). Looking at the perspective of the UMIE, the statistics show that the average percentage of the population ages 65 and above to total population had increased rapidly from 1960 to 2017. As shown in figure 1, the increased was almost doubled from 4 per cent in 1960 to 9.68 per cent in 2017. Even though the percentage in 2017 was relatively small (not a doubledigit), the numbers are increasing soon due to a decline in the fertility rate (Pascual-Saez, Cantarero-Prieto, \& Manso, 2019) as well as a rise in the longevity (Teixeira, Nagarajan, \& Silva, 2017). It is as a result of a rapid improvement in the health and medical sector.

The labour force will decline as a fertility rate declines. As a result, the production level in an economy will decrease if the firms still use the labour-intensive method of production. Hence, the production method should change towards the capital-intensive consistent with the fourth industrial revolution. The needs for the economic transformation are highly crucial as the economic structure is evolving towards the use of robotics, artificial intelligence, technological advancement and machine learning (Teixeira et al., 2017). In embracing these upcoming challenges, the countries should invest more on the development 
expenditures such as technological advancement, research and development, innovation as well as human capital investment. Nevertheless, the increasing trend in the number of the ageing population might require the government to allocate a higher amount of funds for the operating expenditures rather than the development expenditure. It is a saddening truth as the development expenditure is highly crucial for the UMIE to uplift their economic status to the high-income economies. If this condition persists, the UMIE may not be able to remain competitive in the world arena as more funds are channelled towards the operating expenditures due to the increase in the ageing population. It is with the expense of the low development projects, that are highly vital for the acceleration of the economic growth. Therefore, this paper intends to answer the following research objective:

- To investigate how the rise in the ageing population affects the economic growth of the UMIE.

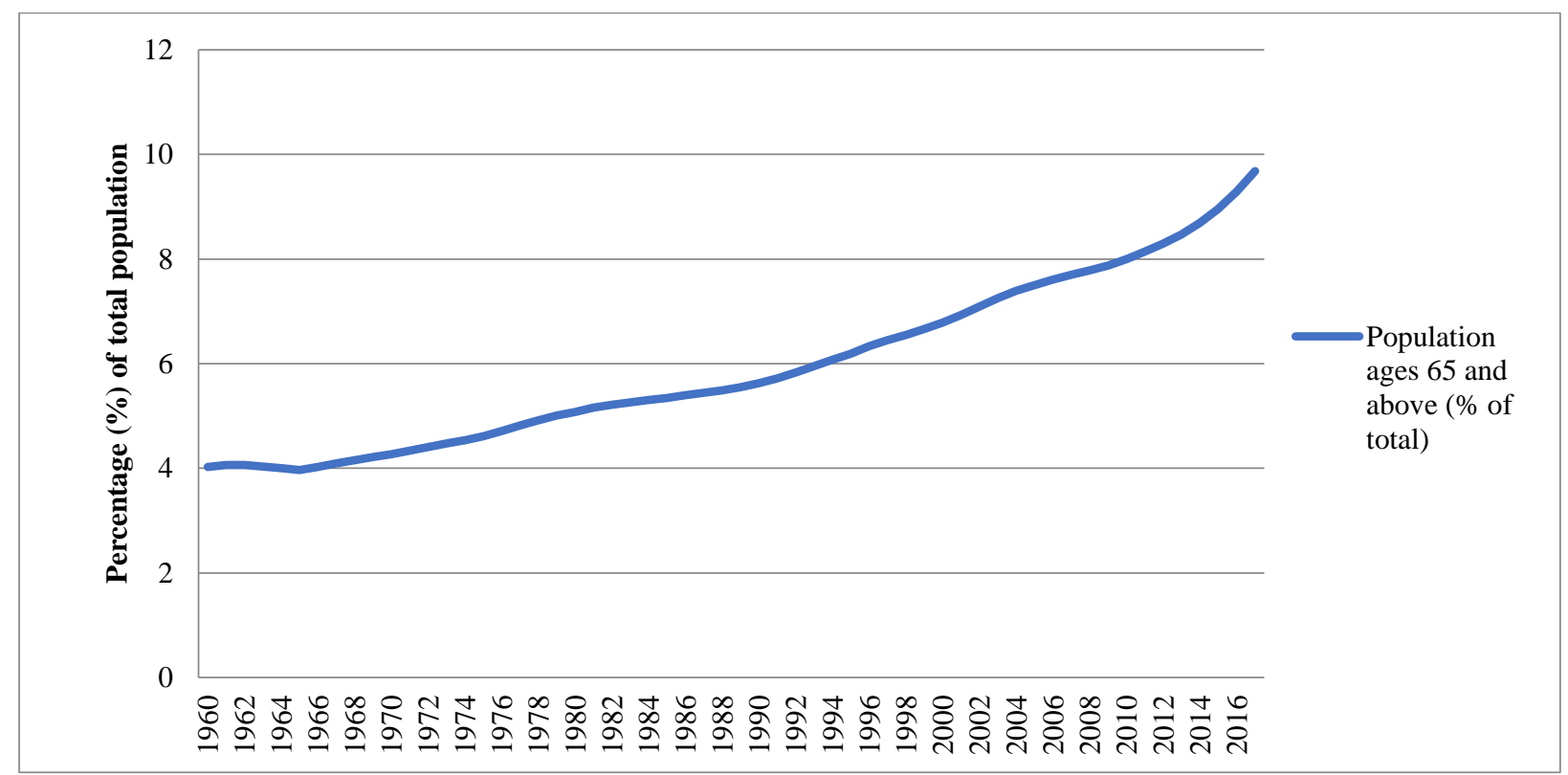

Figure 1: The percentage of the ageing population out of the total population in the UMIE from 1960 to 2017

The motivation of this study is twofold. Firstly. this topic is highly essential as the empirical investigation on this matter is relatively scarce in the growth literature (Mamun, Rahman, \& Khanam, 2020). Secondly, this study is focusing on the UMIE because they are being trapped in the middle-income position for a long period of time (The World Bank Group, 2018b) and still striving to achieve a high-income nation. They might not be able to do so if they have to sacrifice their development expenditure to support the ageing population. Hence, the findings can be used by the government and the policymakers to understand the impacts that the ageing population may give to the economy. Consequently, it helps them to prioritize the areas for improvement for future economic growth.

\section{Theoretical Review}

The endogenous growth model (Lucas, 1988; Romer, 1986) stresses the importance of labour, capital and human capital in ensuring the growth of an economy. These three elements are highly crucial to increase the productivity of a country. Nevertheless, as the ageing population increases and fertility rate declines, the availability and quality of labour force are subject to 
further investigation. It is because the rise in the ageing population leads to an increase in the burden of the working-age population. Hence, the working-age population might have to push themselves in ensuring better living condition. From one perspective, it is good as the productivity will increase. However, the quality of the works is questionable. As a result, the economic growth will increase but not at an exponential rate, especially when the quality of the works is not at the optimum level.

By linking the subjects of the ageing population and economic growth, the theory of secular stagnation (Jackson, 2019) explains its relationship. This theory explains that the economy might be facing a slow growth for an extended period. Usually, the slowdown occurs due to recession, crisis or any unexpected events. It may last for a short period until the economy can adjust itself automatically through any stabilization policies conducted by the government. Be it the fiscal policy, monetary policy or direct measures. However, the rise of the ageing population might cause continuous or permanent effects on economic slowdown. It happens through the changes of consumptions, savings and government expenditures.

Similarly, the theory of intergenerational social contract relates the impact of the ageing population and the economic growth via three main mechanisms, namely public expenditure, savings and consumption (Hillman, 2003). The idea behind the intergenerational social contract lies based on the following assumptions. During the retirement years onwards, let us assume that the older generation has no or limited savings as well as investment. They also have lack of assets to be sold for their future consumptions. At the same, the foods that are available now cannot be stored for future intake. Due to these assumptions, the older people will have to depend on their children. These children, typically comprise of middleage income earners, are having dilemmas in maintaining and uplifting their standard of living. At one point, they want to maximize their full potential by embarking themselves with jobs that pay a higher income. Among the reasons are to buy new assets, to pay for the bills, to take care of their spouse and kids, and to accumulate more savings for future retirement. At another point, they also have a conflict in addressing the needs of their older parents who are already in the retirement age (Hillman, 2003). It is like a social contract between generations, just like what their parents did when they were young. Their parents perceived that they would conduct the same act when they reach the retirement age. This conflict would then limit their ability to fulfil their needs and wants, thus leading to lower consumption and lower economic growth.

Nevertheless, it creates painful effects on the government if the middle-age income earners are unable to support their older parents (Marcum \& Treas, 2013). The burden falls under the responsibilities of the government since they aim to maximize the citizens' welfare. In this case, the government is responsible for allocating more funds in supporting the ageing population, especially when dealing with their medical expenses and facilities, age-friendly infrastructures and subsidies. In this regard, higher taxation will assist the government in supporting the needs of the ageing population as well as other needs for development purposes. Nevertheless, as the government imposes taxes, cost of living is expected to rise. The middle-aged people would have to work more hours in order to cover the increase in their daily expenses. Besides, they start to limit the number of children in order to reduce their expenses (Hock \& Weil, 2012). Consequently, the increase in the ageing population will further create the burden to the whole agents in the economy as the fertility rate declines.

\section{Empirical Review}

The consumption (measured by the purchasing power), is expected to decrease as the ageing population increases. It is because the elders would save most of their pension funds for 
future consumptions rather than the current ones (Acemoglu \& Restrepo, 2017). They will be more independent to survive in the future due to the availability of their savings in the pension funds. However, if savings become the primary source of spending for the ageing population, their rate of savings will diminish from time to time. In maintaining their daily life, the retirees will change the consumption pattern. Significant reduction in consumption by the ageing population is expected, especially in demand for housing and the need for outside food (Teixeira et al., 2017). These people prefer to utilize whatever they have in possession rather than buying new products. Besides, due to having more leisure time, they will substitute outside food consumption with home-cooked food. As a result of lower expenditures by the ageing population, it may create an adverse effect on economic growth.

Furthermore, due to a rise in the number of the ageing population, the government may channel most of their budgets for the operating expenditures rather than the development expenditures (R. Nagarajan, Teixeira, \& Silva, 2017; Teixeira et al., 2017). It is because the costs to maintain the social security expenditure, retirement benefits, transfer payments and pensions will increase rapidly. One of the reasons is because a large proportion of the elders came from professionals and semi-professionals (Acemoglu \& Restrepo, 2017), which necessitate the government to allocate higher pensions for them. It is confirmed by previous studies that found similar findings, especially in the cases of the United States (Atkins, 2016), China (Guo, Liu, \& Liu, 2016) and Japan (Lee \& Shin, 2019; Miranda, 2018). Consequently, it becomes one of the main challenges of the government since they should allocate the budgets on other critical areas that are more productive such as research and development, infrastructure development and education. For instance, the government must prioritize their budget allocations on critical areas such as upgrading the environments that are tailored for the older generation (Teixeira et al., 2017). The transportation system, public facilities and housing areas must be changed consistently with the needs of the older people who demand a safety and clean environment. The allocations for more productive expenditures, which are the engines of growth such as infrastructure development and education, have to be sacrificed (Nagarajan et al., 2017). Consequently, it becomes one of the greatest challenges for the government to restore the public confidence if most of the funds are channelled to the older generation rather than the younger ones. The issue of fairness on the allocation of funds may arise among the younger generation who would be asking for more budgets on critical areas such as research and development, innovation, education, infrastructure development and others. More expenditure to support baby-boomers in the expense of other productive expenditures resulted to a decline in investments in critical areas, thus slowing down the economic growth of a nation.

Given the budget constraint, the government might opt to borrow funds from the external sources. It is mainly to finance infrastructure development that requires a substantial amount of funds (Teixeira et al., 2017). Nevertheless, the country is at the risk of not being able to pay back the external financing due to the instability in the external market. In light of this, it is highly crucial to investigate how ageing population affects the economic growth of the UMIE, and does the external debt plays a significant role in stimulating the growth of the countries.

\section{Methodology}

The Cobb-Douglas production function is an initial step to specify the economic growth model of the UMIE. It is written as follows: 


$$
Y=K^{\propto} L^{1-\propto}
$$

where $\mathrm{Y}$ is the aggregate output, $\mathrm{K}$ is the capital, $\mathrm{L}$ is the labour while $\alpha$ and $1-\alpha$ are both representing the share of capital and labour in the national income. These two elements are considered as control variables in the economic growth model as they are highly essential in influencing the economic growth of a country. In investigating the relationship between the ageing population and the economic growth in the UMIE, we can write the model specification as in equation (2).

$$
y_{i t}=\propto_{i}+\beta_{1} A G E_{i t}+\sum_{j=1}^{k} \beta_{j} x_{i t j}+\varepsilon_{i t}
$$

where $y$ is the growth of national income, $\alpha i$ is the country-specific effect; AGE is an exogenous variable representing the ageing population, $x$ is a set of control variables, $\beta$ is the coefficient of the control variables, $\varepsilon$ is the error term, while $i$ and $t$ represent country and time respectively. The control variables $(x)$ include the two main elements in the CobbDouglas production function, namely labour and capital. The proxy of labour is the population growth (Karadam, 2018; Pegkas, 2019) while the indicators to represent the capital are the ratio of the gross capital formation to GDP (Akram, 2016; Brida, Gómez, \& Seijas, 2017) as well as gross savings to GDP (Gomez-Puig \& Sosvilla-Rivero, 2018). We also include other control variables following previous literature such as average years of secondary schooling as a proxy of human capital (Karadam, 2018; Kim, Ha, \& Kim, 2017), trade openness (Fashina, Asaleye, Ogunjobi, \& Lawal, 2018) and inflation rate (Arčabić, Tica, Lee, \& Sonora, 2018). We include human capital variable, in-line with the endogenous growth model. We also include external debt to GDP as another control variable since it is another source of capital for the countries to finance its expenditure (Shkolnyk \& Koilo, 2018). Thus, equation (2) can be rewritten as follows:

$y_{i t}=\alpha_{i}+\beta_{1} A G E_{i t}+\beta_{2} P O P G_{i t}+\beta_{3} G C F_{i t}+\beta_{4} S A V_{i t}+\beta_{5} H C_{i t}+\beta_{6} T_{i t}+\beta_{7} I N F_{i t}+\beta_{8} E D E B T_{i t}+\varepsilon_{i t}$

All data were derived from the World Development Indicator (WDI) and International Debt Statistics (IDS) by the World Bank as well as the Penn World Table (PWT). The data comprises of 32 countries from 1990 to 2018. Appendix 1 shows a list of countries under investigation. Following Ahlborn and Schweickert (2018) as well as Ewaida (2017), all data were averaged into five-year non-overlapping averages to minimize the effects of short-run business cycle fluctuations. Hence, the period $(t)$ for this study is six for each country. It consists of (1) 1990 to 1994, (2) 1995 to 1999, (3) 2000 to 2004, (4) 2005 to 2009, (5) 2010 to 2014, and (6) 2015 to 2018.

Prior to the estimation technique, we conduct a Cooks' $D$ test to check the existence of the outliers in the data set (Bollen \& Jackman, 1990). In light of this, we calculate the Cook's $D$ distance from the entire sample. Then, the cut-off distance is generated based on a formula of 4 divided with the number of observations. Any distance more than the cut-off distance is the outliers, hence should be removed to ensure unbiased and robust estimation. This procedure is preferable as it does not remove the whole observations for countries that have outlier cases. Instead, this procedure will remove outliers for extreme observations only. It is 
essential as the results from the analysis can represent most of the countries within the UMIE. Previous researches often neglect this procedure (Mencinger, Verbic, \& Aristovnik, 2015).

Due to small number of time (6) but a large number of cross-sections (32), this study employed the two-step system Generalized Method of Moments (GMM). Even though the number of cross-sections is not extensive, previous papers that employed the same method with cross-sections of 24 to 40 (Mencinger et al., 2015; Teixeira et al., 2017; Zhang, Hao, Lu, \& Deng, 2018), have successfully published their findings in reputable journals (journals with ranks of Q1 and Q3). Their estimation results were also robust to other estimation techniques. Hence, the use of GMM as the method of estimation is unquestionable.

The reasons for selecting GMM are threefold. Firstly, this method is applicable for data with large cross-sections and small period (Arellano \& Bond, 1991). Secondly, there is an endogeneity problem when the growth model includes the debt variable (Kim et al., 2017; Sikandar \& Wahid, 2019). The reason being is because the EDEBT and y are subject to reverse causality. Therefore, other traditional panel data estimators such as panel ordinary least square (POLS), fixed effect (FE) and random effect (RE) are inappropriate (Nickell, 1981). Instead, GMM is able to solve the endogeneity problem (Arellano \& Bond, 1991; Law, 2018). Finally, the GMM is also useful as it allows potential heterogeneity across countries by including the country-specific effect ( $\alpha$ i) in the model specification. Hence, the use of system GMM requires the researchers to transform a static model as in equation (3) into a dynamic model by including the lag of the dependent variable. The dynamic model suits the system GMM is written as follows:

$y_{i t}=\alpha_{i}+\delta y_{i t-1}+\beta_{1} A G E_{i t}+\beta_{2} P O P G_{i t}+\beta_{3} G C F F_{i t}+\beta_{4} S A V_{i t}+\beta_{5} H_{i t}+\beta_{6} T_{i t}+\beta_{7} I N F_{i t}+\beta_{8} E_{D E B T}+$ $\varepsilon_{\text {it }} \quad(4)$

Table 1 presents the descriptions of the variables. In ensuring the robustness of the results, we estimate equation (4) by using two proxies of ageing population separately. The first proxy is the old-age dependency ratio (AGE1) while the second proxy is the ratio of population aged 65 and above to total population (AGE2). Hence, we develop two models from equation (4) by replacing the AGE variable into AGE1 and AGE2, respectively. The estimation results are robust if the signs and significance of all variables are consistent throughout both models.

Table 1: Description of the variables

\begin{tabular}{lllll}
\hline Notation & Description of the Variables & Proxy & Units & Sources \\
\hline Y & Real GDP per capita growth & Economic growth & Percentage & WDI \\
yit-1 & Initial real GDP per capita & Convergence & Natural & WDI \\
& & variable & logarithm & WDI \\
AGE1 & Old age dependency ratio & Ageing population & Percentage & WDI \\
AGE2 & Ratio of population ages 65 and above to & Ageing population & Percentage & \\
& total population & & & WDI \\
POPG & Population growth & Labour & Percentage & WDI \\
GCF & Ratio of gross capital formation to GDP & Capital & Percentage & WDI \\
SAV & Ratio of gross savings to GDP & Capital & Years & PWT \\
HC & Average years of secondary schooling & Human capital & Percentage & WDI \\
TO & Sum of export and import to GDP & Trade openness & Index & WDI \\
INF & Consumer price index & Inflation & Percentage & IDS \\
EDEBT & Ratio of external debt stock to GDP & Public debt & \\
\hline
\end{tabular}


As shown in equation (4), $\delta$ represents a coefficient for a dynamic variable (yit-1). Consistent with the conditional convergence hypothesis (Barro, 1991; Barro \& Sala-i-Martin, 2004), the value of $\delta$ is negative $(\delta<0)$. The hypothesis argues that the developing countries can converge to their steady-state of the development path at a higher rate relative to the developed countries. However, when they reached a steady-state, their growth starts to decline as other countries catch-up with the development via product imitation and technological diffusion.

We employed the two-step system GMM since it is efficient relative to the one-step system GMM (Ibrahim \& Law, 2016). Besides, due to the endogeneity problem, this method requires the use of instruments to replace the endogenous variables (in this case: yit-1 and EDEBTit). Other variables were assumed to be strictly exogenous. Since it is difficult to find other variables that are almost similar to the endogenous variables, we used the lag values of the endogenous variables as the instruments.

In ensuring the accuracy of the estimations, the Hansen J test is conducted to check the validity of the instruments (Hansen, 1982). The idea is to ensure that the null hypothesis of overidentifying restrictions is not rejected, hence the instruments are valid. Besides, the Arrelano-Bond test is employed to check the existence of the second-order serial correlation (Arellano \& Bond, 1991). If the null hypothesis of no second-order serial correlation is rejected, the model is not valid since it has misspecification error. Besides, the number of lags used in the instruments must not be too large. Or else, it will cause estimation bias (Roodman, 2009). In examining this issue, the best number of lags is the one that is lesser than the number of cross-sections (32). Therefore, by referring to these rules, we have conducted multiple series of estimations that involved multiple combinations of lags in order to yield the best estimation results. The best result is the one that suits all three diagnostic tests.

\section{Findings}

As illustrated in Table 2, the minimum and the maximum values of all variables show an increasing trend. Nevertheless, potential outliers exist for TO, INF and EDEBT since there were significant differences between the minimum and maximum values.

Table 2: Descriptive statistics

\begin{tabular}{cccccc}
\hline No. & Variable & Mean & Standard Deviation & Minimum & Maximum \\
\hline 1 & $\mathrm{y}$ & 2.324726 & 3.15748 & -12.5760 & 11.2728 \\
2 & $\mathrm{yt}-1$ & 8.521685 & 0.543178 & 6.5918 & 9.5362 \\
3 & AGE1 & 11.0126 & 5.104181 & 4.8954 & 31.6043 \\
4 & $\mathrm{AGE} 2$ & 7.132542 & 3.614813 & 2.6664 & 20.6056 \\
5 & POPG & 1.177353 & 1.135407 & -1.5050 & 5.2075 \\
6 & $\mathrm{GCF}$ & 24.67995 & 6.63747 & 12.6640 & 49.9950 \\
7 & $\mathrm{SAV}$ & 22.46649 & 13.337 & -28.0356 & 56.0171 \\
8 & $\mathrm{HC}$ & 2.526 & 0.427367 & 1.4676 & 3.4891 \\
9 & $\mathrm{TO}$ & 72.05042 & 33.63603 & 15.5664 & 205.5394 \\
10 & $\mathrm{INF}$ & 1290.627 & 16878.62 & -0.1210 & 232662.3 \\
11 & $\mathrm{EDEBT}$ & 45.10432 & 26.89197 & 1.4447 & 166.1601 \\
\hline
\end{tabular}

Therefore, we have conducted a Cook's D test to the entire sample of 189 observations with a cut-off distance of 0.021164 . Table 3 shows the observations that have Cook's D distance 
more than 0.021164 for both models with AGE1 and AGE2, respectively. These observations were removed to ensure robust estimations.

Table 3: Observations with outliers based on Cook's D test

\begin{tabular}{|c|c|c|c|c|c|}
\hline \multicolumn{3}{|c|}{ Model 1 (with AGE1) } & \multicolumn{3}{|c|}{ Model 2 (with AGE2) } \\
\hline Obs. No. & Country & $\begin{array}{ll}\text { Cook's } & \mathrm{D} \\
\text { Distance } & \end{array}$ & Obs. No. & Country & $\begin{array}{l}\text { Cook's D } \\
\text { Distance }\end{array}$ \\
\hline 1 & Albania & 0.1437043 & 1 & Albania & 0.1422738 \\
\hline 7 & Algeria & 0.0217515 & 7 & Algeria & 0.0217920 \\
\hline 12 & Algeria & 0.0405108 & 12 & Algeria & 0.0416184 \\
\hline 21 & Armenia & 0.0379465 & 21 & Armenia & 0.0378907 \\
\hline 37 & Brazil & 0.1252748 & 37 & Brazil & 0.1252900 \\
\hline 43 & Bulgaria & 0.0621392 & 43 & Bulgaria & 0.0622715 \\
\hline 52 & China & 0.0220548 & 52 & China & 0.0222927 \\
\hline 109 & Kazakhstan & 0.0984010 & 107 & Jordan & 0.0263024 \\
\hline 110 & Kazakhstan & 0.0324752 & 109 & Kazakhstan & 0.0985854 \\
\hline 111 & Kazakhstan & 0.0383876 & 110 & Kazakhstan & 0.0330668 \\
\hline 139 & Peru & 0.0895400 & 111 & Kazakhstan & 0.0421360 \\
\hline 145 & Romania & 0.0246373 & 139 & Peru & 0.0892517 \\
\hline 151 & Russian Federation & 0.0695583 & 145 & Romania & 0.0239903 \\
\hline & & & 151 & Russian Federation & 0.0683672 \\
\hline
\end{tabular}

Apart from that, the correlation values of all independent variables were less than 0.8 , except for AGE1 and AGE2 (0.9935). It explains the needs of forming two separate models for AGE1 and AGE2 in order to avoid multicollinearity problem.

Table 4: Correlation values of all independent variables

\begin{tabular}{|c|c|c|c|c|c|c|c|c|c|c|}
\hline & $y_{i t-1}$ & AGE1 & AGE2 & POPG & GCF & SAV & $\mathrm{HC}$ & TO & INF & EDEBT \\
\hline$y_{i t-1}$ & 1 & & & & & & & & & \\
\hline AGE1 & & 1 & & & & & & & & \\
\hline \multirow[t]{2}{*}{ AGE2 } & 0.140 & 0.993 & 1 & & & & & & & \\
\hline & & - & & & & & & & & \\
\hline \multirow[t]{2}{*}{ POPG } & 0.078 & 0.743 & -0.768 & 1 & & & & & & \\
\hline & - & - & & & & & & & & \\
\hline \multirow[t]{2}{*}{ GCF } & 0.129 & 0.130 & -0.093 & 0.039 & 1 & & & & & \\
\hline & & - & & & & & & & & \\
\hline SAV & 0.345 & 0.184 & -0.159 & 0.203 & 0.550 & 1 & & & & \\
\hline \multirow[t]{2}{*}{$\mathrm{HC}$} & 0.124 & 0.583 & 0.606 & -0.481 & -0.125 & -0.188 & 1 & & & \\
\hline & - & - & & & & & & & & \\
\hline \multirow[t]{2}{*}{ TO } & 0.055 & 0.016 & -0.012 & 0.121 & 0.095 & 0.048 & 0.258 & 1 & & \\
\hline & - & - & & & & & & & & \\
\hline INF & 0.110 & 0.021 & -0.026 & -0.170 & -0.028 & -0.102 & 0.021 & -0.006 & 1 & \\
\hline EDEBT & 0.068 & 0.264 & 0.237 & 0.022 & -0.281 & -0.366 & 0.302 & 0.355 & -0.104 & 1 \\
\hline
\end{tabular}

Table 5 illustrates the findings of the two-step system GMM, which was conducted by considering the robust standard error (Windmeijer, 2005). The finding for the convergence 
variable is in-line with the previous literature (R. Nagarajan et al., 2017). Consistent with the convergence hypothesis, the coefficients of yit- 1 in both models are negative and significant, ranging from -3.182217 to -3.260145 . Since this variable is the only variable in the log form, the actual values are ranging from -0.031822 to -0.032601 . It is parallel to the findings by Barro (1991), in which the values should range from 0 to 1 . The closer the value to 1 , the faster the speed of convergence for the countries to achieve a steady-state level. In this case, the UMIE can converge to its steady state of growth but at a slower rate. It confirms that the UMIE is facing with a middle-income trap position due to its ability to converge to its best growth level at a slower rate. Besides, the negative sign validates the use of a dynamic model using system GMM.

Moreover, all control variables are significant and consistent with the previous literature, except for the TO. Similarly, we found the variables under investigation (AGE1 and AGE2) to be negative and significant, consistent with the theory of secular stagnation (Jackson, 2019). These results were valid since the $p$-values of both Arrelano-Bond (AR2), and Hansen tests were insignificant. Both models are free from second-order serial correlation. Besides, the instruments used to replace the endogenous variables are valid.

Furthermore, the numbers of instruments in both models were smaller than the number of countries. Thus, it confirms that the estimation results were unbiased. Overall, the results were robust because the signs and significance of all variables are the same in both models.

Table 5: Panel data estimation using two-step system GMM

\begin{tabular}{|c|c|c|}
\hline & Model 1 & Model 2 \\
\hline & Coefficient & Coefficient \\
\hline \multirow[t]{2}{*}{$y_{i t-1}$} & $-3.182217 * * *$ & $-3.260145 * * *$ \\
\hline & (0.659) & (0.599) \\
\hline AGE1 & $\begin{array}{c}-0.092679 * * \\
(0.047)\end{array}$ & \\
\hline AGE2 & & $\begin{array}{c}-0.192229 * * * \\
(0.072)\end{array}$ \\
\hline POPG & $\begin{array}{c}-1.036486 * * * \\
(0.146)\end{array}$ & $\begin{array}{c}-1.046613^{* * *} \\
(0.193)\end{array}$ \\
\hline GCF & $\begin{array}{c}0.158239 * * * \\
(0.050)\end{array}$ & $\begin{array}{c}0.202437^{* * *} \\
(0.043)\end{array}$ \\
\hline SAV & $\begin{array}{c}0.088107^{* *} \\
(0.041)\end{array}$ & $\begin{array}{c}0.071140 * * \\
(0.033)\end{array}$ \\
\hline $\mathrm{HC}$ & $\begin{array}{c}2.338579 * * * \\
(0.792)\end{array}$ & $\begin{array}{c}2.648456 * * * \\
(0.763)\end{array}$ \\
\hline TO & $\begin{array}{c}0.002576 \\
(0.009)\end{array}$ & $\begin{array}{c}0.008246 \\
(0.009)\end{array}$ \\
\hline INF & $\begin{array}{c}-0.003659 * * * \\
(0.000)\end{array}$ & $\begin{array}{c}-0.003657^{* * *} \\
(0.000)\end{array}$ \\
\hline EDEBT & $\begin{array}{c}0.034514^{* *} \\
(0.014)\end{array}$ & $\begin{array}{c}0.045614^{* * *} \\
(0.013)\end{array}$ \\
\hline Constant & $\begin{array}{c}18.758889 * * * \\
(4.875) \\
\end{array}$ & $\begin{array}{c}17.417252^{* * * *} \\
(4.516) \\
\end{array}$ \\
\hline Observations & 176 & 175 \\
\hline Number of countries & 32 & 32 \\
\hline No. of instruments & 29 & 29 \\
\hline AR2 $p$-value & 0.151447 & 0.186845 \\
\hline Hansen p-value & 0.483975 & 0.621933 \\
\hline
\end{tabular}

Note: ${ }^{* * *}$ and ${ }^{* *}$ indicate $1 \%$ and $5 \%$ significant levels respectively, and values in 
parentheses are the robust standard errors.

\section{Discussion}

The sign of AGE1 in model 1 indicates a negative relationship between the old-age dependency ratio and economic growth of the UMIE. The possible reason is as follows. An increase in AGE1 requires the working-age population to limit their private consumptions and allocate some of their money for the elderly (their parents). As a result, the children, who are in the working-age population might have to sacrifice their needs and wants. It is to support their parents' needs, especially in the forms of monthly stipends, healthcare and groceries. The situation is worsened when the working-age population has a lower fertility rate (Hock \& Weil, 2012). Due to the high cost of living, they might opt to limit the number of children in order to reduce their expenses. Despite an increase in the number of the workingage population, the increase is not at a promising rate. Their burden to support the older generation is increasing as the number of ageing population increases. As a result, private consumption and private investment will start to diminish, and it gives an adverse effect on the economic growth of a country.

Meanwhile, the negative sign of AGE2 gives a different interpretation on the UMIE's economic growth. As the number of elderly ages 65 years old and above (AGE2) increases, the economy is lacking with the number of successors who will be the future labour supply (Horioka, Morgan, Niimi, \& Wan, 2018). The situation is worsened when the fertility rate is declining (Hock \& Weil, 2012; Miranda, 2018). It is proven by looking at the statistics by the World Bank (The World Bank Group, 2018a), in which the average fertility rate for 32 countries under investigation in 2000 to 2017 was declining from 2.54 to 2.14. It means that the average number of children that a woman gave birth was 2.14 in 2017. Detail statistics on the average fertility rate of the UMIE in 2000 and 2017 is shown in Appendix 2. The labour supply will decline as the fertility rate declines. It leads to a deterioration in the accumulation of tax revenues since the ones who are paying the taxes are usually the working-age population. A reduction in the tax revenues will give a negative effect on the economy, as the government is unable to conduct the development projects that are essential for the economic growth of a country.

Also, as the number of ageing population increases, the government has to spend more on the operating expenditure such as pensions, retirement benefits, social security and transfer payments (Carbonaro, Leanza, McCann, \& Medda, 2018; Horioka et al., 2018; R. Nagarajan et al., 2017). This type of expenditure does not give higher value-added to economic growth as compared to the development expenditure. As mentioned earlier, a reduction in the fertility rate will reduce the accumulation of potential tax revenue for the government. Hence, they have problems in allocating their funds, either for development projects or welfare maximization, especially for the ageing population. If they allocate higher funds for the operating expenditures, they have to sacrifice some of the development projects that are highly essential for economic growth.

Moreover, the negative relationships for both AGE1 and AGE2 on y indicate that the number of the ageing population is reaching an alarming state. Even though the average percentage of the ageing population in the UMIE is relatively small (less than 10 per cent), the governments should consider this issue seriously. Or else, it will only contribute to a higher financial burden for the government. As the level of fertility rate keeps declining, the governments need to embark with specific plans to overcome the adverse effects. The plans can be related to the investments in the critical areas under the fourth industrial revolution, 
such as artificial intelligence, machine learning and robotics. The reason being is to increase the total factor productivity by substituting labours into capital. It can further uplift the economic growth of the countries even when the economies are facing a high number of the ageing population and low level of fertility rate.

Apart from the above, the government should not neglect investment in human capital. By looking at Table 5, the coefficients of $\mathrm{HC}$ in both models were the highest among all other variables. Besides, they were also highly significant. Therefore, we recommend the governments in the UMIE to focus on the education, training, re-training and any other types of human capital investments, especially in the critical areas as outlined in the previous paragraph. The budget allocation on this educational sector should not be jeopardized even when the countries are facing sudden economic or political shocks.

\section{Conclusion and Policy Recommendation}

Regardless of the proxy of the ageing population, the increase in both AGE1 and AGE2 give adverse effect to the economic growth of the UMIE through two main channels, namely private consumption and government spending. Firstly, the adverse effect is channelled through a lower private consumption by the working-age populations who have to support the older people, mainly their parents. Secondly, the rise in the ageing population necessitates the government to allocate more funds for the operating expenditures rather than the development expenditure. Consequently, less development projects can be embarked to accelerate the economic growth. Due to these negative effects, the countries in the UMIE will further be in the middle-income trap position, especially when the number of the ageing population increases over time. The challenge is on the governments, on how they want to allocate their limited budget to maximize the welfare of the citizen. It is suggested that their fiscal policy initiatives should not focus too much on the operating expenditure, especially on pensions, transfer payments, subsidies, and retirement benefits. Instead, they should prioritize the development expenditure, particularly on education, technological advancements as well as research and innovation. Failure to do so will only push them into a more in-depth challenge that requires further government intervention.

\section{Contribution of the Study}

This research contributes to the literature in three different ways. Firstly, it contributes to the ageing-growth literature, which is relatively scarce (Mamun et al., 2020). Secondly, even if there were previous researches that have conducted similar analyses (Abeywardhana, 2019; Mamun et al., 2020; Teixeira et al., 2017), they failed to integrate the external debt into the model. This variable is essential as the majority of the countries in the UMIE are relying on the external debt to stimulate their economic growth. Reliance on the variables as stipulated in the endogenous growth model is not sufficient in the current challenging scenario. Finally, previous research did not remove outliers because they want to capture all essential characteristics and components in the data. However, the estimation results might subject to biased estimation (Abdul Bahri, 2018) since the existence of the outliers might change the signs of the variables.

\section{Suggestion for Future Research}

For future research, we suggest that the researchers examine how an increase in the ageing population affects the public debt of the countries. Some pieces of evidence show that the government's financial burden increases due to the rise in the ageing population. 
Nevertheless, how much is the impact on the domestic and external debts is subject to further investigation. This issue is relevant because the rise in the public debt might also hinder the economic growth of the countries, then further push the UMIE into the middleincome trap position. If it happens, the UMIE might not be able to remain competitive as they are residing in the same economic status for long period.

\section{Acknowledgments}

The authors would like to thank the reviewers for their thoughtful comments and efforts towards improving our manuscript.

\section{References}

Abdul Bahri, E. N. (2018). Pelaburan langsung asing, pembangunan kewangan, kemeruapan kadar pertukaran asing dan pertumbuhan ekonomi. Universiti Kebangsaan Malaysia.

Abeywardhana, D. K. Y. (2019). The Impact of ageing population on economic growth in South Asia. Asian Social Science, 15(7), 70. https://doi.org/10.5539/ass.v15n7p70

Acemoglu, D., \& Restrepo, P. (2017). Secular stagnation? The effect of aging on economic growth in the age of automation. American Economic Review, 107(5), 174-179. https://doi.org/10.2139/ssrn.2899142

Ahlborn, M., \& Schweickert, R. (2018). Public debt and economic growth - economic systems matter. International Economics and Economic Policy, 15(2), 373-403.

Akram, N. (2016). Public debt and pro-poor economic growth evidence from South Asian countries. Economic Research-Ekonomska Istrazivanja, 29(1), 746-757. https://doi.org/10.1080/1331677X.2016.1197550

Arčabić, V., Tica, J., Lee, J., \& Sonora, R. J. (2018). Public debt and economic growth conundrum: Nonlinearity and inter-temporal relationship. Studies in Nonlinear Dynamics and Econometrics, 22(1), 1-20. https://doi.org/10.1515/snde-2016-0086

Arellano, M., \& Bond, S. (1991). Some tests of specification for panel data: Monte Carlo evidence and an application to employment equations. Review of Economic Studies, 58(2), 277-297. https://doi.org/10.2307/2297968

Atkins, G. L. (2016). Aging in America: An agenda for an era of new possibilities. Generations, 40(4), 6-8. Retrieved from

http://uml.idm.oclc.org/login?url=http://search.ebscohost.com/login.aspx?direct=true $\& d b=c 8 h \& A N=120750488 \&$ site $=$ ehost-live

Barro, R. J. (1991). Economic growth in a cross section of countries. Quarterly Journal of Economics.

Barro, R. J., \& Sala-i-Martin, X. (2004). Economic Growth. The MIT Press (2nd editio). England: The MIT Press. https://doi.org/10.1016/0025-5408(96)80018-3

Bollen, K. A., \& Jackman, R. W. (1990). Regression diagnostics: An expository treatment of outliers and influential cases. Modern Methods of Data Analysis, 257-291.

Brida, J. G., Gómez, D. M., \& Seijas, M. N. (2017). Debt and growth: A non-parametric approach. Physica A: Statistical Mechanics and Its Applications, 486, 883-894. https://doi.org/10.1016/j.physa.2017.05.060

Carbonaro, G., Leanza, E., McCann, P., \& Medda, F. (2018). Demographic decline, population aging, and modern financial approaches to urban policy. International Regional Science Review, 41(2), 210-232. https://doi.org/10.1177/0160017616675916

Ewaida, H. Y. M. (2017). The impact of sovereign debt on growth: An empirical study on GIIPS versus JUUSD countries. European Research Studies Journal, 20(2), 607-633. 
Fashina, O. A., Asaleye, A. J., Ogunjobi, J. O., \& Lawal, A. I. (2018). Foreign aid, human capital and economic growth nexus: Evidence from Nigeria. Journal of International Studies, 11(2), 104-117. https://doi.org/10.14254/2071-8330.2018/11-2/8

Gomez-Puig, M., \& Sosvilla-Rivero, S. (2018). Public debt and economic growth: Further evidence for the euro area. Acta Oeconomica, 68(2), 209-229. https://doi.org/10.1556/032.2018.68.2.2

Guo, Z., Liu, L., \& Liu, X. (2016). Population aging, marginal propensity to consume and economic growth. Asian Economic and Financial Review, 6(9), 534-546. https://doi.org/10.18488/journal.aefr/2016.6.9/102.9.534.546

Hansen, L. (1982). Large sample properties of generalized method of moments estimators. Econometrica, 50, 1029-1054.

Hillman, A. L. (2003). Public finance and public policy: Responsibilities and limitations of government. United Kingdom: Cambridge University Press.

Hock, H., \& Weil, D. N. (2012). On the dynamics of the age structure, dependency and consumption. Journal of Population Economics, 25, 1019-1043.

Horioka, C. Y., Morgan, P. J., Niimi, Y., \& Wan, G. (2018). Aging in Asia: Introduction to Symposium. Review of Development Economics, 22(3), 879-884. https://doi.org/10.1111/rode.12545

Ibrahim, M. H., \& Law, S. H. (2016). Institutional quality and CO2 emission-trade relations: Evidence from Sub-Saharan Africa. South African Journal of Economics, 84(2), 323-340. https://doi.org/10.1111/saje.12095

Jackson, T. (2019). The post-growth challenge: Secular stagnation, inequality and the limits to growth. Ecological Economics, 156, 236-246. https://doi.org/10.1016/j.ecolecon.2018.10.010

Karadam, D. Y. (2018). An investigation of nonlinear effects of debt on growth. Journal of Economic Asymmetries, 18, 1-13. https://doi.org/10.1016/j.jeca.2018.e00097

Kim, E., Ha, Y., \& Kim, S. (2017). Public debt, corruption and sustainable economic growth. Sustainability, 9(3), 433. https://doi.org/10.3390/su9030433

Law, S. H. (2018). Appled panel data analysis: Short panels. Serdang: Universiti Putra Malaysia Press.

Lee, H. H., \& Shin, K. (2019). Nonlinear effects of population aging on economic growth. Japan and the World Economy, 51, 1-38. https://doi.org/10.1016/j.japwor.2019.100963

Lucas, R. E. (1988). On the mechanics of economic development. Journal of Monetary Economics, 22(1), 3-42.

Mamun, S. A. K., Rahman, M. M., \& Khanam, R. (2020). The relation between an ageing population and economic growth in Bangladesh: Evidence from an endogenous growth model. Economic Analysis and Policy, 66, 14-25. https://doi.org/10.1016/j.eap.2020.02.001

Marcum, C. S., \& Treas, J. (2013). The intergenerational social contract revisited: Crossnational perspectives. United States of America: The Johns Hopkins University Press.

Mencinger, J., Verbic, M., \& Aristovnik, A. (2015). Revisiting the role of public debt in economic growth: The case of OECD countries. Engineering Economics, 26(1), 61-66.

Miranda, A. E. R. (2018). Finding opportunities in Japan's aging population. CIRSS Commentaries, 5(7), 5-7.

Nagarajan, N. R., Teixeira, A. A. C., \& Silva, S. T. (2016). The impact of an ageing population on economic growth: An exploratory review of the main mechanisms. Analise Social, 51(218), 4-35. 
Nagarajan, R., Teixeira, A. A. C., \& Silva, S. (2017). The impact of population ageing on economic growth: A bibliometric survey. Singapore Economic Review, 62(2), 275-296. https://doi.org/10.1142/S021759081550068X

Nickell, S. (1981). Biases in dynamic models with fixed effects. Econometrica, 49(6), 14191426.

Pascual-Saez, M., Cantarero-Prieto, D., \& Manso, J. R. P. (2019). Does population ageing affect savings in Europe? Journal of Policy Modeling, 1-34.

Pegkas, P. (2019). Government debt and economic growth: A threshold analysis for Greece. Peace Economics, Peace Science and Public Policy, 25(1), 1-7. https://doi.org/10.1515/peps-2018-0003

Romer, P. M. (1986). Increasing returns and long-run growth. Journal of Political Economy, 94(5), 1002-1037.

Roodman, D. (2009). A note on the theme of too many instruments. Oxford Bulletin of Economics and Statistics, 71(1).

Shkolnyk, I., \& Koilo, V. (2018). The relationship between external debt and economic growth: Empirical evidence from Ukraine and other emerging economies. Investment Management and Financial Innovations, 15(1), 387-400. https://doi.org/10.21511/imfi.15(1).2018.32

Sikandar, M. J., \& Wahid, F. E. (2019). Debt and economic growth of Pakistan: Role of uncertain economic and political conditions. Business \& Economic Review, 11(2), 83106. https://doi.org/10.22547/ber/11.2.5

Teixeira, A. A. C., Nagarajan, N. R., \& Silva, S. T. (2017). The impact of ageing and the speed of ageing on the economic growth of least developed, emerging and developed countries, 1990 - 2013. Review of Development Economics, 21(3), 909-934. https://doi.org/10.1111/rode.12294

The World Bank Group. (2018a). Data catalog: World development indicators. Retrieved September 16, 2018, from https://datacatalog.worldbank.org/dataset/worlddevelopment-indicators

The World Bank Group. (2018b). World Bank analytical classifications. Retrieved September 17, 2018, from https://blogs.worldbank.org/opendata/new-country-classificationsincome-level-2019-2020

Windmeijer, F. (2005). A finite sample correction for the variance of linear efficient two-step GMM estimators. Journal of Econometrics, 126, 25-51.

Zhang, Z., Hao, Y., Lu, Z. N., \& Deng, Y. (2018). How does demographic structure affect environmental quality? Empirical evidence from China. Resources, Conservation and Recycling, 133(February), 242-249. https://doi.org/10.1016/j.resconrec.2018.02.017. 
INTERNATIONAL JOURNAL OF ACADEMIC RESEARCH IN BUSINESS AND SOCIAL SCIENCES Vol. 10, No. 5, May, 2020, E-ISSN: 2222-6990 ㄷ 2020 HRMARS

\section{Appendices}

Appendix 1: List of countries under investigation

\begin{tabular}{|c|c|c|c|}
\hline & \multicolumn{2}{|c|}{ Countries } & Total \\
\hline $\begin{array}{l}\text { Countries } \\
\text { Included in } \\
\text { the Study }\end{array}$ & $\begin{array}{c}\text { Albania } \\
\text { Algeria } \\
\text { Argentina } \\
\text { Armenia } \\
\text { Belize } \\
\text { Botswana } \\
\text { Brazil } \\
\text { Bulgaria } \\
\text { China } \\
\text { Colombia } \\
\text { Costa Rica } \\
\text { Dominican Republic } \\
\text { Ecuador } \\
\text { Gabon } \\
\text { Guatemala } \\
\text { Islamic Republic of } \\
\text { Iran }\end{array}$ & $\begin{array}{c}\text { Jamaica } \\
\text { Jordan } \\
\text { Kazakhstan } \\
\text { Malaysia } \\
\text { Mauritius } \\
\text { Mexico } \\
\text { Paraguay } \\
\text { Peru } \\
\text { Romania } \\
\text { Russian Federation } \\
\text { Serbia } \\
\text { South Africa } \\
\text { Sri Lanka } \\
\text { Thailand } \\
\text { Turkey } \\
\text { Venezuela }\end{array}$ & 32 \\
\hline $\begin{array}{l}\text { Countries } \\
\text { Excluded } \\
\text { from the } \\
\text { Study }\end{array}$ & $\begin{array}{c}\text { American Samoa } \\
\text { Azerbaijan } \\
\text { Belarus } \\
\text { Bosnia Herzegovina } \\
\text { Cuba } \\
\text { Dominica } \\
\text { Equatorial Guines } \\
\text { Fiji } \\
\text { Georgia } \\
\text { Grenada } \\
\text { Guyana } \\
\text { Iraq } \\
\text { Kosovo } \\
\text { Lebanon }\end{array}$ & $\begin{array}{c}\text { Libya } \\
\text { Maldives } \\
\text { Marshall Islands } \\
\text { Montenegro } \\
\text { Namibia } \\
\text { Nauru } \\
\text { North Macedonia } \\
\text { Samoa } \\
\text { St. Lucia } \\
\text { St. Vincent \& The } \\
\text { Grenadines } \\
\text { Suriname } \\
\text { Tonga } \\
\text { Turkmenistan } \\
\text { Tuvalu }\end{array}$ & 28 \\
\hline Total & & & 60 \\
\hline
\end{tabular}

Note: 28 countries were excluded due to data unavailability. 
INTERNATIONAL JOURNAL OF ACADEMIC RESEARCH IN BUSINESS AND SOCIAL SCIENCES Vol. 10, No. 5, May, 2020, E-ISSN: 2222-6990 @ 2020 HRMARS

Appendix 2: Fertility rate of 32 countries in the UMIE in 2000 and 2017

\begin{tabular}{|c|c|c|c|}
\hline No. & Countries & 2017 & 2000 \\
\hline 1 & Albania & 1.71 & 2.16 \\
\hline 2 & Algeria & 2.71 & 2.51 \\
\hline 3 & Argentina & 2.28 & 2.56 \\
\hline 4 & Armenia & 1.60 & 1.65 \\
\hline 5 & Belize & 2.48 & 3.60 \\
\hline 6 & Bostswana & 2.68 & 3.39 \\
\hline 7 & Brazil & 1.71 & 2.30 \\
\hline 8 & Bulgaria & 1.54 & 1.26 \\
\hline 9 & China & 1.63 & 1.50 \\
\hline 10 & Colombia & 1.83 & 2.39 \\
\hline 11 & Costa Rica & 1.77 & 2.37 \\
\hline 12 & Dominican Republic & 2.39 & 2.89 \\
\hline 13 & Ecuador & 2.46 & 3.03 \\
\hline 14 & Gabon & 3.72 & 4.54 \\
\hline 15 & Guatemala & 2.92 & 4.60 \\
\hline 16 & Islamic Republic of Iran & 1.64 & 2.21 \\
\hline 17 & Jamaica & 1.99 & 2.58 \\
\hline 18 & Jordan & 3.31 & 4.03 \\
\hline 19 & Kazakhstan & 2.73 & 1.80 \\
\hline 20 & Malaysia & 2.02 & 2.78 \\
\hline 21 & Mauritius & 1.44 & 1.99 \\
\hline 22 & Mexico & 2.15 & 2.72 \\
\hline 23 & Paraguay & 2.45 & 3.55 \\
\hline 24 & Peru & 2.37 & 2.93 \\
\hline 25 & Romania & 1.64 & 1.31 \\
\hline 26 & Russian Federation & 1.76 & 1.20 \\
\hline 27 & Serbia & 1.46 & 1.48 \\
\hline 28 & South Africa & 2.43 & 2.83 \\
\hline 29 & Sri Lanka & 2.03 & 2.24 \\
\hline 30 & Thailand & 1.47 & 1.67 \\
\hline 31 & Turkey & 2.03 & 2.50 \\
\hline \multirow[t]{2}{*}{32} & Venezuela & 2.29 & 2.82 \\
\hline & Average & 2.15 & 2.54 \\
\hline
\end{tabular}

